\title{
ECONOMICS
}

\section{THIRTY YEARS OF ECONOMICS: UWA AND THE WA BRANCH OF THE ECONOMIC SOCIETY FROM 1963 TO 1992}

by

\author{
Michael McLure \\ Business School \\ The University of Western Australia
}

DISCUSSION PAPER 09.18 



\title{
Thirty Years of Economics: $U W A$ and the WA Branch of the Economic Society from 1963 to $1992^{1}$
}

\author{
Michael McLure*
}

\begin{abstract}
This paper overviews the evolution of economics at the University of Western Australia (UWA) in the thirty years to 1992, with attention given to the leadership of professorial staff, fragmentation in the vision for the economics program and the role of research and research training in that program. The study also considers the place of the Western Australian (WA) Branch of the Economic Society of Australia in economics in this State. Notwithstanding some significant fragmentation within the $U W A$ economics department, which had to be confronted when developing a unified view on the direction of the economics program, the thesis of the study is that the department met with considerable success as it worked to re-balance its program. In regard to the WA Branch of the Economic Society, two main issues have emerged: the success of the Shann memorial lecture, which is undertaken in partnership with $U W A$; and a progressive reduction in the participation of senior $U W A$ economists in the administration of the Society's WA Branch.
\end{abstract}

\footnotetext{
1 I would like to acknowledge the assistance of UWA archivists, Maria Carvalho, Mim Congdon and Narelle Crighton for allowing me access to a range of documents and to thank Mark David, Manager of HR Services at UWA, for permission to examine a number of staff files. I am also indebted to the following past and present economists from UWA who either talked to me about the project or provided me with comments: Reginald Appleyard, Roger Bowden, Ken Clements, Robin Ghosh, Ray Petridis, Darrell Turkington and Douglas Vickers. Thanks also to Simon Mongey, for compiling Appendices 3 and 4, John Roberts, for providing a copy of his 1979 class notes on monetary economics, and Rony Gabbay, for providing his list of publications. The initial plan for this paper provided for consideration of economics at the WA Institute of Technology / Curtin University of Technology, Murdoch University and the WA College of Advanced Education / Edith Cowen University. To that end, I spoke with, or received comments from, Peter Kenyon, Robert Leeson, Margaret Nowak, Herb Thompson and Malcolm Tull. However, that project turned out to be too unwieldy and the paper was reduced to its current form. I thank these people for their assistance and apologise for not being able to utilise their comments.
} 


\section{$1 \quad$ Introduction}

This paper examines two themes related to the evolution of economics in Western Australia between 1963 and 1992. The primary theme concerns the development of the economics program at UWA. The secondary theme concerns the WA Branch of the Economic Society of Australia, with particular reference to the Shann memorial lecture and the contribution of UWA Staff to the Society's WA Branch.

The development of the economics program at $U W A$ in the thirty years to 1992 was marked by a mix of inertia and particular views developed in isolation, which lead to some fragmentation in the department of economics. By 1987 the department had been reviewed and recommendations were made to redress the imbalance in the program. But notwithstanding these problems and challenges, the main feature of economics at $U W A$ is its improvement and success in the course of the review period. In this paper most, though not all, attention is directed towards the role played by professorial staff because they oversaw much of the education program and/or guided and undertook research. As a consequence, Ian Bowen (economics and demography), Reginald Appleyard (demography and economic history), Douglas Vickers (financial markets and economics), Roger Bowden (applied economics) and Kenneth Clements (demand analysis and international economics) feature more prominently in this paper than other staff.

For ease of exposition, the primary theme is presented in three parts. Section 2 examines the first fifteen years (1963 to 1977), mainly dealing with the forces for long term change that led to an excessive prominence of economic history units within the economics program and an undervaluation of research by staff. Section 3 examines the second fifteen years (1978 to 1992), pointing to the factors that led to a review of the economics department in 1987 and the successful changes made immediately prior to, and after, that review. Section 4 includes some general comments on $U W A$ economics graduates and raises a few miscellaneous matters that are anecdotal in character but still provide some context.

The secondary theme of this study is examined in a single section of the paper. The place of the WA Branch of the Economic Society of Australia in WA economics is examined with reference to: the significance of the Shann memorial lecture, $U W A$ 's decreasing participation in the WA Branch of the Society (other than through coconvening the 'Shann') and the increased role of economists from 'new' universities, especially Curtin University of Technology and Murdoch University. 


\section{$2 \quad$ Economics at $U W A: \mathbf{1 9 6 3 - 1 9 7 7}$}

In 1963 the economics program at $U W A$ was headed by Professor Ivor Ian Bowen (MA Oxon.), a very traditional English gentleman in his mid-fifties who had a habit of requiring staff to attend morning tea each day. Whether this was to foster a social sense among colleagues or to audit staff attendance is uncertain, although some staff from the period suspected the latter. Prior to commencing at $U W A$ in 1958, Bowen ${ }^{2}$ enjoyed a wide ranging career at many prestigious institutions, including: All Souls College Oxford, where he was a fellow from 1930 to 1937, the Oxford Institute of Statistics, where he was a researcher from 1935 to 1941, Harvard University, where he was a research fellow in 1954; and the University of Hull, where he was professor of economics from 1947 to 1958 . At the time, Bowen's reputation as a scholar largely rested on his monograph Britain's Industrial Survival (Bowen 1947) and his handbook on Population (Bowen 1954).

Bowen was supported by a range of senior lecturers in economics that ended up having long careers at UWA: Merab Harris ( $P h D$ Lond) on economic history, Wilfred Dowsett (MEc Syd) on mathematical economics, Des Oxnam, (MA N.Z.) on labour economics and industrial relations, Alexander Kerr (PhD W.Aust.) on regional accounting and economic history and Arnold Cook (PhD Harv). The other senior lecturers in economics were to shortly leave $U W A$ : Neil Laing, who left $U W A$ in 1965, and C. A. Cannegieter (Drs Ec NHHS) who left $U W A$ in 1967, but at the time he was prominent for his work on the economic and social aspects of the Ord river scheme (Cannegeiter 1964, Musgrave and Lewis 1965). The economics program also enjoyed the services of a senior lecturer in 'economic geography', Joseph Gentilli ( $D$. Pol Sc. Univ. Econ. Inst. Venice) and a senior lecturer in 'public administration', V. Subramamian (PhD ANU). Economics lecturers at that time who contributed to the discipline at $U W A$ for extended periods include Ron Peters and Ray Petridis. Leslie A. Clarkson was the remaining lecturer in economics.

Unfortunately, the $U W A$ library no longer stocks a copy of the undergraduate handbook for 1963, but it stores copies of almost all subsequent handbooks. Based on the 1964 handbook and the record of faculty discussion for changes introduced in that year, the 3 year 'pass' degree is comprised of 10 full year units, which must include (i) 'economics' at first year, second year and third year levels, 'economic and social statistics' at first year level and either 'mathematics' or 'economic history' at first year level; and (ii) the units from one of 5 'courses' of specialisation, namely 'mathematical economics and/or statistics', 'economic history', 'politics and public administration', 'industrial relations' and 'geography'. ${ }^{3}$ As is still the case today, 'honours' was undertaken in the $4^{\text {th }}$ year of the degree.

The logic underlying these five economic streams, and the units taught within them, appears to have had as much to do with staff availability as with any rationale for curriculum development. Indeed, one reason why 1963 is notable is that it was the first year that monetary economics was introduced - a unit that has endured until this

\footnotetext{
${ }^{2} \mathrm{He}$ was generally referred to as 'Ian' (and not 'Ivor') Bowen. He also published under the name 'Ian Bowen'.

${ }^{3}$ Optional units offered included 'History of Economic Thought', 'Agricultural Economics' and 'Social Economics' as well as units that were directly linked specialisations within the degree.
} 
day. Curiously though, the memo written on 30 January 1962 from Arnold Cook to the Dean of the Faculty (Ian Bowen) requesting the introduction of this unit was partly justified on the basis of equitable treatment of staff:

"I would think it most unjust if some staff were given the opportunity to teach their own specialised fields (e.g. Industrial Relations, Economic History, History of Economic Thought, Public Administration, Mathematical Economics, Econometrics etc), and the same opportunity were denied to other members of staff (Arnold Cook, UWA Archive 459 part 2, folio 40). ${ }^{4}$

By way of digression, Aimee Tolomei (2005) prepared a very brief but beautiful biographical overview of Cook for the WA Guild of Blind Citizens. Cook was born in Narrogin in 1922 and lived in Geraldton and, at the age of 15, was diagnosed with "Retinitis Pigmentosa", becoming totally blind by the age of 18. After completing his BA at $U W A$, he won a Hackett travelling scholarship to study at the London School of Economics, which he did between 1948 and 1950. His dissertation "the Implication for Wages Theory of the Pricing Policy of the Firm" was supervised by E. H. Phelps-Brown (UWA Archive: Personnel File, Arnold Cook). In the UK Cook acquired the assistance of a black Labrador guide dog called 'Dreena', who accompanied him back to Perth in 1950 to become the first guide dog in Australia. In 1965 Cook went on sabbatical to study at Harvard University with Arthur Smithies and James Duesenberry (UWA Archive: Personnel File, Arnold Cook), eventually obtaining his doctorate from Harvard in 1967. Cook died of a heart attach in 1981 at 59 years of age. His general contribution to society was publicly recognised by the WA Guild of Blind Citizens on 15 October 1985 when a statue of Arnold Cook, together with his guide dog Dreena, was unveiled at the entrance to the Ivy Watson Playground in King's Park. To date, Cook remains the only Western Australian economist to be honoured with a public memorial statue.

In the fifteen years to 1977 , the balance of the economics degree changed in three substantive ways: the decline of economic geography and public administration; the introduction of Japanese studies within the economics program; and a rise in the prominence of economic history. Leadership of the program also changed during this period.

Joseph Gentilli ${ }^{5}$ and V. Subramamian had moved out of the economics program in the late 1960s as the geography and public administration streams were taught outside the department of economics. This marked the beginning of the decline

\footnotetext{
4 John Roberts, a student of Arnold Cook in 1979, has kept the unit outline for Cook's 1979 class in "Monetary Economics 210". The outline is a very high quality document. It includes a summary of each lecture topic and is supported by around fifty references for each topic. Roberts has also kept the lecture notes that he took during Cook's lectures in this unit.

${ }^{5}$ In February 2009 the Geographical Association of WA introduced the Joseph Gentilli Memorial Award. It noted:

"Dr Joseph (Joe) Gentilli, as a 27year-old, arrived in Fremantle in 1939 and soon obtained a job teaching statistics at the University of Western Australia. However, his main interest was geography and he gradually designed and built up a Geography course until it eventually became its own department at the university. Dr Gentilli was known as the "father of Australian Climatology", (Geographical Association of Western Australia 2009, p. 21)
} 
in these streams within the economics program and by the mid-1970s they were dropped from the economics degree.

The Japanese studies stream was introduced within the economics degree in the late 1960s. In part this was motivated by the growing ties between Australia and Japan as a result of the export of mineral and petroleum products from North West Australia to Japan. The Chair in Japanese studies was inaugurated in 1968 when the post was awarded to J. B. Conyngham, but his appointment was brief. In 1970 Bernard Key ( $M E c$ Calif.), a specialist in Japanese management systems, was appointed to the position and played the crucial role in establishing the program. From when he departed UWA in 1977 until 1984 the position remained vacant. Takashi Takayama (PhD Hokkaido Imp.), a Japanese economist who specialized in spatial and intertemporal economics $(1971,1994)$, was appointed in 1984 and held the post until 1992, when the program moved out of the Faculty of Economics and Commerce (although Takayama remained in the Faculty as professor of economics until 1994). While the Japanese program was initially established with an economic emphasis, the core element of the Japanese studies program became language - with a full year language unit (or two semester units) taught in each year of the degree - with a Japanese courtyard being added at the suggestion of Professor Key as a physical instrument to assist students with the leaning of language and understanding Japanese culture.

While there was some coverage of Japanese culture in this stream, there was virtually no interaction between the Japanese studies major and the rest of the economics program. The one exception was Japanese history, which was also taught within the economic history major. Typically, Bachelor of Economics students undertaking a major in Japanese studies graduated with knowledge of two complementary but distinct fields: economics and Japanese language.

The greatest change, however, occurred in the area of economic history. In 1963, the Faculty agreed that students in the first year of the economics program may chose between Mathematics 10 and Economic History 10 (UWA archive 459 Part 2, folio 82), although, because Merab Harris was on extended leave, the requirement was not implemented until 1965 (UWA archive 459 Part 2, folio 98). In 1964, the Faculty Sub-Committee, comprising Ian Bowen, Christopher Savage (Head of Commerce), Merab Harris and Ray Petridis, recommended the establishment of a Chair in economic history (UWA archive 459 Part 2, folio 122), thereby enabling one economic history unit to be offered in first year and another as a fourth year honours class. In her penultimate year at UWA, Merab Harris and her junior colleague Leslie A. Clarkson ${ }^{6}$ prepared a subsequent memo outlining the case for an expansion in the economic history program (UWA archive 459 Part 2, folio 125-126). They argued that the economic history professor should be appointed no later than 1967, so that a new

\footnotetext{
${ }^{6}$ Leslie Clarkson (PhD Nottingham) was a lecturer in economic history but left the UWA economics program in 1966, which was a major loss to the program. He went on to become Professor of Social and Economic History at Queen's University in Belfast and published numerous articles and chapters on European economic and social history. Clarkson was made a member of the Royal Irish Academy in 1990 and is currently Emeritus Professor of Social History at Queens University. His major books include Death, Disease and Famine in Pre-industrial England (1976), Proto-industrialisation: the First stage of Industrialisation (1985) and A University in Troubled Times: Queen's Belfast, 1945-2000 (2004).
} 
third year economic history unit could also be introduced and a second year unit introduced shortly thereafter. Their proposals were justified on the basis of tradition and the need to feed the honours unit in economic history.

"The joint study of economic principles and economic history has a long and valuable tradition within the discipline of economics, and the faculty should not cut off the study of Economic History at the second year for students who wish to work within this tradition...

... at the moment we lose contact with students at the end of second year, ${ }^{7}$ and only one or two return to economic history in the fourth year (Merab Harris and Leslie Clarkson, UWA Archive 459 part 2, folio 125-126).

This became the blueprint for the development of economic history sequence within the economics program. In 1966 Wayne Frank (MS Utah State, PhD Ohio State) was appointed as a senior lecture and most importantly, Reginald Appleyard was appointed professor of economic history in 1967, when a third year economic history unit was also introduced. In 1969 a second year economic history unit was also introduced.

Prior to his appointment at UWA, Appleyard was a senior fellow in demography at the Australian National University and had acquired a solid reputation for his research into migration through studies like the Socioeconomic Determinants of Assisted Emigration from the United Kingdom to Australia (1976). While at UWA, he continued to work in this area, with studies like Immigration: Policy and Progress (1970), Ten Pound Immigrants (1988) and International Migration Today (1988) and as editor of International Migration. He also extended his research interests into core areas of economic history, such as The Beginning: European Discovery and Early Settlement of Swan River, Western Australia (1979). In addition, he worked on a longitudinal study on the settlement of Greek females in Australia between 1964 and 2008 , resulting in a range of scholarly articles. ${ }^{8}$ During the period of Appleyard's stewardship, the economic history stream continued to grow with the support of economists with an interest in economic development, namely: Robin Ghosh (PhD Birm.) and Rony Gabbay (DPolSc, Geneva), both of whom commenced at UWA in 1968, and Ian vanden Driesen (PhD, Lond), who commenced in 1970.

Prior to appointment at UWA, Ghosh trained as an historian of economic thought, under the supervision of Terence Hutchison, by investigating the relationship between classical economics and colonization. Among other things, two of his studies were published in Economica $(1963,1964)$ and a monograph was published under the title Classical Macroeconomics and the Case for Colonies (1967). ${ }^{9}$ After arriving at

\footnotetext{
${ }^{7}$ The UWA handbook for 1964 does not record any economic history unit for second year students only first year and fourth year.

${ }^{8}$ Appleyard is currently consolidating the major findings from this long running longitudinal study, which he hopes to publish as a book.

9 Craufurd Goodwin (1968) reviewed this book for Economica and, after contrasting Terence Huthison's comment in the preface that it is the "first full account of this subject" with Donald Winch's (1965) Classical Political Economy and Colonies, published two years earlier, suggested that "In bringing forth his book at this time Dr Ghosh may be the victim of deplorable delays as well as execrable production by his Indian publishers" (1968, p. 314).
} 
UWA, Ghosh undertook research in development economics, as in the book Agriculture in Economic Development (Ghosh1977), but he also continued his research interest in the history of economics ${ }^{10}$ Prior to employment with UWA, Rony Gabbay published on the history of Jews in Iraq (Gabbay 1954) and worked as a research associate and principal contributor to the Middle East Record (Aron 1960 and 1961). He successfully advocated in favour of introducing 'Middle East Economies' units within the economic history stream across a range of years in the economics degree. His early UWA research culminated in the publication of Communism and Agrarian Reform in Iraq (Gabbay 1978). Ian vanden Driesen arrived at UWA in 1970, but had taken his PhD at the LSE in the mid-1950s where he was a friend of fellow PhD student Helen Hughes (Lodewijks 2007, p.435). His interests were in labour movements, history and development, and it was in this broad area that he undertook research at UWA (vanden Driesen 1986, 1994). Development themes within the works of Ghosh, Gabbay and vanden Driesen grew over the period of their tenure at UWA, peaking in the second part of the period considered in this paper (as discussed in Section 3).

Appleyard was also supported by economic historians without any significant interest in development studies, most notably Pamela Statham (PhD UWA) and Mel Davies (MA Adel.). Pamela Statham started work at UWA in 1966 as a young academic, when she undertook postgraduate training and teaching duties. She subsequently undertook research on the Swan River Colony (Statham 1981), colonial statistics (Butlin, Ginswick, Statham 1986), sandalwood in WA (Statham 1988), the origins of Australia's capital cities (1989) and, most importantly, she wrote the definitive biography of James Stirling (Statham-Drew 2003). Mel Davies joined UWA in 1976, teaching many economic history classes, authoring the well regarded 'Corsets and Conception: Fashion and Demographic Trends in the Nineteenth Century' (Davies 1982) and undertaking research into the origins of South Australia (Davies 1989). ${ }^{11}$

In this environment, the economic history stream prospered within the teaching program. By the end of the 1960s, the first year economic history unit at UWA dealt with Britain between 1760 and 1960, the second year economic history unit examined American and Russian economic history between 1860 and 1960 and the third year economic history unit was presented in two parts: Australian economic history between 1788 and 1960 and Japanese economic history between 1860 and 1960. The honours unit in history was a mixture of topics ranging from methodology (the 'new' economic history) to historical demography. At that stage, all these courses were offered over a one year period but with the advent of semesters, eight economic history units were offered at the end of the 1970s. The economic history stream also included Robin Ghosh's unit on the history of economic analysis.

\footnotetext{
${ }^{10}$ While at UWA Ghosh did not publish his HET research in refereed journals, two of his departmental discussion papers were influential: 'Adam Smith on Capital Accumulation and Growth' (Ghosh 1984) was an extension of an earlier unpublished paper that attracted favourable comment from Walter Eltis (1975) and 'John Stuart Mill on colonies and colonization' (Ghosh 1985) was published in a collection on John Stuart Mill (Wood 1987).

${ }^{11}$ More recently Davies became the foundation editor of the Journal of Australasian Mining History, from its inception in 2003 until today.
} 
Another consequence of Appleyard's arrival at UWA was the introduction of a second professor to the economics department which carried with it the potential to disturb the pattern of leadership within the program. In 1969, Bowen was 'Head of Department' and while he was on study leave that position was abolished. A new position entitled "Chairman of Department" was then created and awarded to Appleyard. It should be stressed that this was not the result of any 'Machiavellian' scheming by Appleyard. To the contrary, it was the result of lobbying by professors from outside the economics program and by staff from within the economic program, who had come to appreciate his consultative approach when dealing with staff. Consistent with that approach, Appleyard worked closely with Ghosh when chairing the activities of the department. ${ }^{12}$ Bowen, however, was clearly disappointed as he had understood that his appoint as professor of economics meant that he was also head of the department. In 1971 he commenced unpaid leave to work at the International Bank for Reconstruction and Development (which, when considered in conjunction with its sister organisation, the International Development Association, is usually referred to as the World Bank) in Washington. On 22 March 1972, when writing to $U W A$ 's Vice Chancellor to seek an extension to his leave, he wrote:

"Another factor which leads me to ask for extension of unpaid study leave is the organisation of the Economics Department since my return from study leave in 1969 has not provided me with satisfactory conditions of work" (Personnel file - Ian Bowen, UWA Archive S85/5, folio 176).

Bowen's leave was extended until he retired in 1973. At the World Bank he served as the editor of the Bank's journal Finance and Development from 1974 to 1977. However, it should be noted that, notwithstanding the personal disappointment he felt, Bowen acted with considerable dignity and continued to support the UWA economics program. On learning that Douglas Vickers, a professor of economics at the University of Pennsylvania, would replace him at $U W A$, Bowen advised the Vice Chancellor that he would be happy to:

"assist him in any way that I can, this year and next, and will discuss with him how I can help him develop economics in Western Australia." (Personnel file - Ian Bowen, UWA Archive S85/5, folio 176).

Douglas Vickers was born and raised in Queensland and his appointment as professor of economics at UWA enabled him to return to Australia. He remained at UWA from 1972 to 1977. Leaving Japanese studies and industrial relations aside, Vickers found the economics program at $U W A$ was of a varying standard. On the negative side, he points to a deficiency in "the important area of econometrics". Econometrics was included in the program, but was not taught by specialists, and Vickers was of the view that a specialist professor in that area was needed. However, this deficiency was addressed in two ways: Darrell Turkington, a lecturer during Vickers's tenure, undertook a PhD at Berkley and developed considerable expertise in mathematical economics and theoretical econometrics; and Professor Roger Bowden (PhD Manc.) was employed during 1976 - the same year that Vickers went abroad on

12 Appleyard has indicated that his approach to running the department was modeled on that of Professor W. D. Borrie, the head of demography when Appleyard worked at the Australian National University. 
study leave, returning in 1977 at which time he accepted the invitation of a professorial appointment at the University of Massachusetts.

Vickers has also pointed to a disappointing tendency to use standard text books for 'churning material' in classes. However, his most serious criticisms are directed at the program's lack of direction, professionalism and research. On arrival at $U W A$ :

"I found at the time the Economics Department was in fairly complete disarray and it became clear to me that it was not possible to raise it to international standards... No significant research was being done by faculty members and no graduate program of significance existed... one senior member [of staff] who did no research because he claimed that all that could be said in his area of interest had already been said, openly stated that this situation was, for him, his "Shangri La". The department contained too many identifiable cliques whose primary aim was to protect their own parochial interest, and there did not exist ... a Department of unified vision and professional commitment" (Douglas Vickers, correspondence with the author, 27 February 2009)

This assessment of research at $U W A$ appears to be a little too harsh. For example, Ray Petridis started publishing in the History of Political Economy (HOPE) and the Economic Record during Vickers tenure, which laid the foundation for a number of well regarded studies after Vickers departure, most notably his HET studies on economists in government, Alfred Marshall and others (again published in HOPE) and the labour economics and wages policy (published in the Economic Record, Journal of Industrial Relations and UWA's in house journal Economic Activity) ${ }^{13}$. Eventually a special issue of the History of Economics Review was published in Petridis' honour (Leeson 2001), which included an introduction that briefly reviewed his contribution to economics (Flatau and Leeson 2001). In addition, Alexander Kerr was at UWA during the first half of Vickers' tenure. While Kerr's most celebrated works pre-date Vickers arrival in Western Australia, his paper 'Structure of Final Demand in Perth' (Kerr 1973) was published after Vickers's arrival. Indeed, Vickers himself points out that it is to Kerr's credit that he built his academic career at UWA to a point where he gained appointment at the newly established Murdoch University as the foundation professor of economics in 1975. Reginald Appleyard, the departmental chair during this period, was also President of the WA Branch of the Economic Society (1972-74), held the Japan Foundation's 1973 Distinguished Visiting Fellowship and was active providing migration advice in international economic bodies.

Nevertheless, it is clear that Vickers was seriously concerned about the state of economics at $U W A$ and he attempted to correct the deficiencies he saw. He did this by: undertaking productive research at $U W A$, primarily on the interplay between financial markets and process of capital formation, in works like "Finance and False Trading in Non-Tatonnement Markets" (1975) and Financial Markets in the Capitalist Process (1978); inviting distinguished economists from abroad to visit $U W A$, such as Terence

\footnotetext{
${ }^{13}$ In the decade prior to Vickers's arrival, Petridis was the editor of Economic Activity from 1963 to 1969, before Alexander Kerr took over the editorial role (with Robin Ghosh subsequently taking over editorial responsibility for the journal after Kerr's departure fro UWA in 1975 for Murdoch University). Petridis continued to publish in Economic Activity until 1986.
} 
Hutchison, the historian of economic thought who supervised Robin Ghosh, and Sydney Weintraub, a Keynesian economist; and engaging actively in 'service' activities, such as speaking to professional bodies and the press on economic matters and actively participating in the WA Branch of the Economic Society of Australia.. In addition, when Appleyard stood down as head of department in 1976, Vickers nominated for the position as this would place him in a better position to implement the reforms that he felt were necessary. However, his candidacy was not successful; he was defeated in the ballot by David Treloar, a more modest scholar in comparison to Vickers but one with more popular appeal among their colleagues. Treloar (1988 p. 270) subsequently portrayed Vickers as a man with an especially hierarchical view of the world in which the 'professor stood above those of sub-professorial status', inferring that this was the reason why Vickers lost the ballot, and indicating that it was no surprise that Vickers left $U W A$ in the following year. However, this last point is probably overstated as I recall Vickers indicating, in response to a question raised at the 1997 HETSA Conference (University of Notre Dame, Fremantle), that he left WA because the post he was offered at the University of Massachusetts (Amherst) was too good to turndown. ${ }^{14}$ Moreover, while the perception that Vickers looked down upon the activities of non-professorial colleagues was relatively widely held, it was probably a consequence of observers confusing his disdain for poor scholarship, which was his real concern, with disdain for non-professorial scholarship.

Of course, there is also a positive side to Vickers's assessment. He reflected positively on the capacity of the program to produce a small number of well educated honours students and pointed to some good work in economic theory and analysis, macroeconomics and history of economic thought. He also had a great deal of time for the administrative acumen of Robin Ghosh who was then collaborating closely with Appleyard on the direction of the department, advising the University on his departure that Ghosh was worthy of advancement in rank. Perhaps most importantly though, with the passage of time, Vickers's assessment of the economics program subsequent to his departure is much more favourable.

"I hasten to say that I am pleased to have seen that in more recent decades, after what I observed as an extended period of malaise, important progress towards national and international recognition appears to have been made." (Douglas Vickers, correspondence with the author, 27 February 2009)

This latter assessment is generally consistent with the findings of the Section 3, which deals with the second fifteen years of the period under review.

\section{$3 \quad$ Economics at $U W A: \mathbf{1 9 7 8 - 1 9 9 2}$}

By 1978, 'economic history' and 'applied economics' were supported by current professorial appointments: Reginald Appleyard and Roger Bowden respectively. Provision had been made for a professor of economics and a professor of Japanese studies, but these positions were vacant and remained vacant until 1981 in the case of

\footnotetext{
${ }^{14}$ Although, it should be noted that Reginald Appleyard's recollection of Vickers's departure from UWA accords with Treloar's account.
} 
economics, when the 31 year old Kenneth Clements (PhD Chic.) was appointed, and 1984 in the case of Japanese studies, when Takashi Takayama was appointed. Robin Ghosh was also appointed head of the economics department in 1981. The industrial relations stream was developed and taught under the leadership of Associate Professor Des Oxnam, supported by Ruth Johnston and Nicolas Blain, but Oxnam retired in 1979 and was succeeded by Charles Mulvey (MA Aberd.), who was appointed to UWA in 1982 as professor of industrial relations. However, within two years Mulvey had taken the industrial relations program out of the Economics Department and formed a new department, still within the Faculty of Economics and Commerce, which was dedicated to industrial relations. ${ }^{15}$

Consequently, by 1984 the economics program was under Robin Ghosh's direction and organised around four loose streams, each associated with a professor: economic history (Appleyard), economics (Clements), applied economics (Bowden), and Japanese Studies (Takayama). ${ }^{16}$ The places of Appleyard, as professor of economic history, and Takayama, as professor of Japanese studies, have already been briefly reviewed, so it is also appropriate to briefly reflect on Bowden, as professor of applied economics between 1976 and 1988, and Clements, as professor of economics from 1981 until the end of the period covered by this paper. ${ }^{17}$

Darrell Turkington has suggested that Bowden was one of the best economics appointments at $U W A$ during the period of his tenure. In support of this, he pointed out that The Econometrics of Disequilibrium (Bowden 1978) and Instrumental Variables (Bowden and Turkington 1984) were influential studies: both are cited in the literature, with the study on instrumental variables becoming something of a standard reference in applied studies. Moreover, while at $U W A$, Bowden published in leading international journals such as the Journal of Econometrics, the Manchester School, the Journal of Monetary Economics and the Journal of the American Statistical Association.

Kenneth Clements's appointment, made when Appleyard was head, was also very important. Immediately prior to joining UWA, Clements was a research economist at the Reserve Bank of Australia (1979-81) and, prior to that, an assistant professor of economics at Chicago University and had published on trade issues (1980). His subsequent research benefited from the contacts that he made with eminent scholars from Chicago, publishing jointly with Henri Theil and, after his arrival at UWA, working with Larry Sjaastad, his research supervisor at Chicago, to prepare a monograph on How Protection Taxes Exports (Clements and Sjaarstad 1984). Importantly, Clements also arranged for Sjaastad to come to $U W A$ as a visiting scholar on many occasions. The link to Theil was also maintained, not just through

\footnotetext{
${ }^{15}$ Although, as Treloar (1988) has noted, the general decision to establish a separate Industrial Relations Department was largely taken by Faculty in 1977.

16 This arrangement basically reflects the model that Appleyard has often espoused. As a master's student in the UWA economics program in the mid-1980s, I recall Appleyard introducing seminars by observing that there are three fundamental elements to economics: theory, measurement and history. When the Japanese studies area is set aside, as it was eventually moved out of the Faculty, the three remaining Chairs in economics correspond to each of these three fundamental elements: economics, for theory, applied economics, for measurement, and economic history, for history.

${ }^{17}$ Clements still plays a leading role in the economics program at $U W A$, where he is currently head of economics.
} 
the publication of Applied Demand Analysis: Results from System-Wide Approaches (Clements and Theil 1987) but with Theil also visiting UWA. Clements typically characterises his research interests as 'general' economics, which may be supported by his broad range of published research, but consumer analysis and international economics are at the heart of much of his research program.

Notwithstanding the success of Appleyard, Bowden and Clements as individual scholars, the concerns that Vickers had raised over the lack of agreement on a united direction within the economics program continued into the early 1980s and later. Disagreement on academic matters continued to bubble under the surface of the normal routine of the program, even spilling over to the Faculty into the University's Academic Board ${ }^{18}$ and culminated in a review of the $U W A$ economics department by John Ross and Geoff Shellam (Treloar 1988, p. 271), which also drew on independent and confidential reports by external academic economists Fred Gruen and Alan Woodland.

The main concerns raised in the report of the Review have been discussed by David Treloar (1988). In relation to didactic matters, the primary concerns centres on the balance between 'core' and 'peripheral' economics in the economics degree program. For the purposes of the Review, core economics was defined as microeconomics, macroeconomics, econometrics and quantitative economics, effectively covering units that fall within the jurisdiction of the head of department and the professors of economics and applied economics. Peripheral economics was defined as economic history, Middle Eastern studies and Japanese studies, effectively covering units under the jurisdiction of the head of department and the professors of economic history and Japanese studies. The Report recommended an increased emphasis on 'core' economics, especially econometrics, and a decreased emphasis on 'peripheral economics', especially Japanese studies. The report was also critical of the research output of staff, pointing to an attitude of complacency within the department. A disturbing loss of good staff was also reported (citing the loss of Petridis to Murdoch University). Nevertheless, the Review did acknowledge the work of Bowden and Turkington on econometrics and Appleyard's attempts to enhance research on migration and development was also recognised. However it was Clements who was singled out for praise, citing his approach to promoting research in applied and quantitative economics. Robin Ghosh was also complemented for having done a commendable job as head of department in difficult circumstances. While the findings of the Review may be subject to some criticism, on its two fundamental points - the balance of the program and the role of Clements in fostering research in core economics - the findings of the Review were clearly sound. These two fundamental points are considered in turn below.

First, the range of units offered in the economics degree program was unbalanced. Economic history is, of course, a scholarly pursuit and in my view is a necessary element of a quality economics program. However, in the 1980s the stream had grown, with development and Middle East economies also being added.

\footnotetext{
18 David Treloar (1988, p. 271) reports that there was "internecine conflict between two members of the Department of Economics" at the Academic Board meeting to consider funding for the establishment of the Faculty's Economic Research Centre.
} 
However, the 17 units from this stream offered in 1987 were excessive and unsustainable $\mathrm{e}^{19}$ and the axe was set to fall on several units. As Treloar has recorded:

"By 1987 the almost utter absence of research publications regarding USSR, USA, British and Asian economic history creates doubt that[,] in the consolidation of the Department's efforts in line with the recommendations of the Review[,] these diverse strands of teaching will justify retention." (Treloar 1988, p. 276. $)^{20}$

This is not an open-ended criticism of the quality of teaching - many of the lecturers in charge of units in the economics program were actually very good teachers. ${ }^{21}$ The problem with the imbalance is the significant misallocation of resources within the economics department. However, this imbalance was subsequently redressed: the exaggerated prominence of units from the economic history stream diminished and the economics program was made more sustainable and consistent with developments outside Western Australia. The Centre for Migration and Development was also established in January 1987 to more directly support the research of Appleyard and vanden Driesen (migration and demography) and Ghosh and Gabbay (development studies), who wrote or edited books for this centre on themes like: the impact of migration on Australia's socioeconomic development and change in developing economies, with special reference to Indian Ocean islands (Appleyard and Ghosh 1988); small island economies generally (Gabbay, Ghosh and Siddique 1996) and the Seychelles in particular (Gabbay and Ghosh 1992). This centre was also successful in attracting research funding from AusAID and the National Centre for Development Studies. Furthermore, Gabbay and Ghosh continued their supervising of graduate students, ${ }^{22}$ with Abu Siddique, Director of the Centre from 1995, completing his $P h D$ at UWA in 1987 under the supervision of Ghosh.

Second, the emergence of an emphasis on core economic research continued to grow in subsequent years. This was partly achieved through improved recruiting of research active staff at UWA, such as E. Juerg Weber ( $P h D$ Rochester) and

\footnotetext{
${ }^{19}$ In the undergraduate program from 1984 to 1987 , units that fall within the economic history stream are: Economic History 100, Economic History 200, British Economic History 210, Russian Economic History 220, Japanese Economic History 231, Japanese Economic History 232, Australian Economic History 241, Australian Economic History 242, United States Economic History 250, South East Asian Economic History 260, Economic development 220, Population Economics 230, Middle East Economics 270, Middle East Economies 370, Middle East Economies 470, History of Economic Analysis 310, and Topics in Post-War Australian Economic History 410. The economics department introduced a coursework masters program in 1986, which also offered two units from the economic history stream: Topics in Economic History 502; and Topics in Contemporary Middle East Economies 503.

${ }^{20}$ Reginald Appleyard has suggested that Treloar's negative comment on research output should be read in the context of: a rapid rise in student numbers, which placed greater demands on the teaching staff; the introduction of half units, which provided scope for a greater range of units to be offered; and the distorting role played by a particular economic history lecturer who was not inclined to undertaking research.

${ }^{21}$ The author of this paper has very fond memories of the small postgraduate classes he took on Middle East Economies, which was taught by Rony Gabbay, Topics in Economic History, which was taught by Ian vanden Driesen and Reginald Appleyard, and Topics in the History of Economic Analysis, which was taught by Robin Ghosh.

${ }^{22}$ Rony Gabbay has supervised eight PhD theses and at UWA and Ghosh has supervised two.
} 
MoonJoong Tcha ( $P h D$ Chicago). $P h D$ and $M E c$ students tended to carry out their research through the Economic Research Centre and work towards the publication of research in peer reviewed journals, which helped to develop a more journal directed approach to research activity by staff within the department and a stronger research culture among graduate students. For example, between 1987 and 1990, Clements supervised three Master of Economics students undertaking their degrees by thesis ${ }^{23}$ and three $P h D$ students: Saroja Selvanathan at UWA and Antony Selvanathan (at Murdoch), who each undertook applied studies of consumer demand and are currently professors at Griffiths University, and Meher Manzur, who studied exchange rate economics and is currently an associate professor at Curtin University.

Research was further fostered at $U W A$ by better integrating postgraduate research at $U W A$ with similar level economic research undertaken elsewhere in Australia. In 1987, the year of the department's Review, the Economic Research Centre hosted the inaugural "PhD Conference in Economics and Business". 24 This conference was organised by Clements to briefly congregate some of the best research students in Australia at UWA and provide them with: the opportunity to present their research to peers and professors; detailed feedback from a prominent academic discussant; and exposure to serious scholarly debate on their research. The first three $\mathrm{PhD}$ Conferences, held in 1987, 1988 and 1989 we all convened by the Economic Research Centre. By 1991, when the fourth conference was held, it was co-convened by the UWA's Economic Research Centre and the Australian National University's Centre for Economic Policy Research, with the active support of Robert Gregory. From 1992 to this day, the conference has been held annually, convened alternately at $U W A$ and the $A N U$, and has become Australia's premier event for $P h D$ training of economists. Importantly for $U W A$, the conference became a frequent and regular forum in which its students could present their research and have it critically appraised and provide the opportunity place for potential research students to directly observe what they would need to do to become a $P h D$ researcher. The outcome was entirely positive for economic research: nationally, in WA and at $U W A$.

Finally, new research active economists were appointed directly to the economics department in the final years of the period of this study. After spending 1987 to 1989 at $U W A$, Paul Miller ( $P h D$ ANU) returned to the economics program in 1991 as an associate professor. As a result of his studies in labour economics and his active contribution to the design of the economics program in the period following the department's Review, ${ }^{25}$ Miller rose to the office of professor of economics by the mid1990s and subsequently went on to head the department (where he exhibited his

\footnotetext{
${ }^{23}$ Two of these theses concerned consumption economics (alcohol, meat) and one on the economics of protection

${ }^{24}$ The title "PhD conference in Economics and Business" did not emerge until the fourth conference in 1991. The first conference was convened between 1-3 November 1987 at UWA, but was titled the 'Economics Postgraduate Research Conference', the second conference convened in November 1988 prefaced the previous title with the word 'international (i.e. the "International Economic Postgraduate Research Conference') and the third conference, convened in November 1989, reverted to the original title by dropping the word 'international'. Two academic reports on the PhD Conference have since been published, the first by Robert Gregory, Takashi Takayama and Kenneth Clements (1991) and the second by Qiang Ye and Kenneth Clements (1999).

${ }^{25}$ Robin Ghosh also places considerable weight on the importance of Miller's contribution to course structures in the late 1980 s.
} 
capacity to balance onerous administrative responsibilities with an extensive and productive research program). Michael McAleer ( $P h D$ Queens) was another prominent research active scholar to take up an appointment in 1991. While having no aptitude for, or interest in, academic administration, McAleer proved himself to be a prolific researcher. Like Clements and Miller, he was also active in research supervision. Darrell Turkington has indicated that, in addition to undertaking his own research, he saw his role as providing the mathematical and econometric grounding to students so that those with very strong quantitative skills could undertake postgraduate research under McAleer's supervision. ${ }^{26}$

\section{Some Graduates and Other Miscellaneous Matters}

As noted earlier, the main focus of this paper has been directed towards the role that professors played in guiding economics at UWA. Perhaps this approach gives too much prominence to the department's 'growing pains' and under-emphasises the contribution of the many staff and students who kept the 'show in the road'. My purpose has been to advance the proposition that even when these growing pains are identified and explicitly acknowledged, the economics department at $U W A$ was still a success: the general direction set by the early 1990 s was correct. ${ }^{27}$ When attention is directed away from these professors and growing pains and towards graduates and the senior staff who supported the program without having prime responsibility for leading the program, the basically positive propositions underlying this paper are reinforced.

This thesis receives broad support from Reginald Appleyard's (forthcoming) review of the faculties of Business and Law, prepared for inclusion in a volume to celebrate UWA's centenary, which provides an overview of graduates from these faculties who have subsequently been successfully working in public administration or the commercial world. In view of this, there is no need for a detailed review of prominent economic alumni from UWA in this paper. Nevertheless, some insight is gained from a brief reflection on some of the economics theses (honours, masters or $\mathrm{PhD}$ ) that were supervised at $U W A$ in the 30 years from 1963, supported by a few brief observations on the subsequent careers of their authors. ${ }^{28}$ From the $1960 \mathrm{~s}$, there were a number of theses prepared by scholars of subsequent note, including: The development of the official short-term money market in Australia, by Frank Harman, with Harman going on to become a prominent Western Australian economist, both in academia (at Murdoch University) and in public service (as chair of various state government enquiries into energy policy and governance); and Depression and

\footnotetext{
${ }^{26}$ Turkington classes McAleer along with Bowden as the two best research economists to have worked at UWA during his period of tenure.

${ }^{27}$ This is not to say that the path followed from the early 1990s onwards was always smooth. Someone may extend the history of economics at UWA into the $21^{\text {st }}$ Century, and, if they do, they will no doubt find instances of conflicting vision. The point here, however, is that the structure of the UWA economics program in the early 1990 s and the research potential of economics staff employed at UWA provided a suitable basis from which a strong economics program could prosper. It should be noted, however, that this assessment is not shared by all members of Staff from the 1992.

${ }^{28} \mathrm{PhD}$ dissertations undertaken in the UWA economics programs for the period of this study are listed in Attachment 1 and a selection of masters dissertations are listed in Attachment 2.
} 
recovery in Western Australia, 1928/29 - 1938/39: a study in economic change, a masters dissertation by Graeme Snooks that was subsequently published as a book (Snooks 1974). In purely academic terms, Snooks is perhaps the most distinguished graduate from $U W A$ 's economics program from the period under consideration: he is an authority in many aspects of economic history, global transitions and went on to have a successful career as an academic at Flinders and the ANU. During the 1980s, several subsequent economists of note submitted theses. In 1981 Colin Barnett, the current Premier of Western Australia, submitted his thesis on A hedonic price model of consumer demand for urban residential land and the current Dean of the UWA Business School, Tracey Horton, presented her honours dissertation on Exchange rate determination for examination in 1985.

As a former UWA post-graduate coursework student (in 1986 and 1987) I am in a position to provide some anecdotal support for the basically positive thesis of this paper. In addition to those I have already mentioned, I have very favourable recollections of the teaching of John Jackson and Philip Grossman. My colleagues of the time at the WA Treasury undertaking the same degree also talked highly of teachers from courses that I did not take, especially Paul McLeod for his resource economics unit and for his supervision. Of course, such anecdotal feedback has not been uncritical, but it nevertheless reveals a consistent and positive bias.

I would like to conclude this section with the words of Wilfred Dowsett, who taught mathematical economics while serving as a senior lecturer in economics at UWA from 1951 to 1970 . He was not active in research, with his main publications being a text book on Elementary Mathematics in Economics (1959) and 'Poverty in Australia' (1968). But his career path took him towards administration, becoming Dean of Faculty between 1967 and 1968 when the university was undergoing a student 'population boom'. In his post retirement letter to the Vice Chancellor, Professor Clews, dated 11 March 1971, Dowsett commented in a melancholy manner that:

"now my feelings are sharply mixed. My term as Dean followed by sickness meant a year or so of fatigue at the end of which I am only now emerging into a period of regret for unfinished work. Perhaps as time passes, I shall find the regrets exceeding the relief." (Wilfred Dowsett s/185 folio 137)

Although a digression from the primary theme of this paper, the above words have been reported because I found them moving: I will certainly reflect on them as I strive to balance the relative demands of research and administration in a way that enhances job satisfaction.

\section{$5 \quad U W A$ and the WA Branch of the Economic Society of Australia}

At the start of the first decade of this study, UWA was heavily involved with the WA Branch of the Economic Society. Professor Bowen was Branch President and two other senior members of staff (Alexander Kerr and Neil Laing) were committee members. The story is much the same during the rest of the 1960s, a time when $U W A$ was the only university, or tertiary institution, where an education in economics could be obtained. Consequently, significant involvement by UWA staff was to be expected 
and the committee members from industry on the WA Branch of the Society were generally trained at $U W A$. For example, Les McCarrey was a $U W A$ graduate working at the WA Treasury (eventually as the Under Treasurer), J.E. Dolin had submitted his thesis on the timber industry for examination at UWA in 1967, Christopher Vargovic had been mentored by Alexander Kerr at UWA during the 1950s and worked as an economics research officer at the WA Employers' Federation, and Norman Dufty worked on labour economics as a postgraduate student in the late 1950s and early 1960 s, before taking a $\mathrm{PhD}$ at $U W A$ on the organisation of technically oriented education (and later becoming the Dean of Social Sciences at the Western Australian Institute of Technology).

The tradition whereby the UWA Department of Economics and the WA Branch of the Society sponsored the Shann memorial lecture was also continued during the entire period of this review, with H. C. 'Nugget' Coombs presenting the 1963 lecture on 'some ingredients for growth' In the 30 years that followed the 'Shann' was presented by many learned and distinguished scholars and practitioners, with Reginald Appleyard often exploiting his contacts with the Australian National University to ensure high quality presenters. Examples of Shann lectures include: John Hicks's 1967 lecture on 'monetary theory and policy'; John Crawford's 1968 lecture on 'the development of trade policy'; Keith Hancock's 1974 lecture on 'economists ecologists and historians'; Geoff Harcourt's 1975 lecture on 'theoretical controversy and social significance', Peter Groenewegen's 1983 lecture on 'rationalising Australian taxation revisited'; Fred Gruen's 1985 lecture on the question 'how badly is the Australian economy performing and why?'; Noel Butlin's 1989 lecture on 'the great Australian take-over bid'; and Graeme Snooks's 1993 lecture on the question 'does the long-run in economics matter?'. 29

The enthusiasm for the Shann memorial lecture among staff from $U W A$ and members of the Economic Society did not wane over the thirty years covered in this study. In the case of both institutions, the 'Shann' was the premier vehicle for engaging with the broad public on economic matters. UWA also holds the Bateman Lecture, which is a smaller infrequent lecture intended for specialists in the commercial disciplines and which is sometimes presented by prominent overseas economists, ${ }^{30}$ and the Economic Society convenes presentations by visiting economists, especially economists from the Reserve Bank of Australia. But the 'Shann' remains the public face of economics in Western Australia for both UWA and the Economic Society.

However, UWA's prominent position within the WA Branch of the Economic Society progressively diminished as its monopoly on tertiary level education in economics was challenged by competition from programs with economic content associated with the emergence of 'new' institutions: the Western Australian Institute of Technology (WAIT) opened to students in 1968 with its direct successor, Curtin

\footnotetext{
29 The full Shann lecture program for the period under review is shown in Appendix 3 The Shann memorial lectures presented during the 1980s were published by Abu Siddique (1993) and a companion volume of lectures presented during the 1990s was published by Paul Crompton (2004).

${ }^{30}$ Unfortunately UWA's records of Bateman lectures are incomplete and a comprehensive list of Bateman lectures dedicated to economics is not available. Appendix 4 contains a fragmented record of such these lectures.
} 
University of Technology, commencing operations in 1987; Murdoch University opened to students in 1975. Towards the end of the period under review, the WA College of Advance Education acquired university status as Edith Cowen University in 1991 and the University of Notre Dame Australia, the State's first private university, opened to students in 1992.

In the 1960s, the President of the WA Branch of the Society was always from UWA: Ian Bowen (1963-1964), Alexander Kerr (1965-1969). Subsequent to that, a UWA member of the Society was WA Branch President on just one occasion: Reginald Appleyard in 1973. From the 1970s to mid-1980s, presidents tended to be drawn from public service, such as Ron Ewing (Commissioner of State Taxation) in 1974 and 1975, or industry, such as Terence Hogan (from the stock brokers Patersons and later director of the Perth Stock Exchange) in 1979 and 1980, Jeannie M Lyall in 1981 (Perth Chamber of Commerce) and Gregory Hancock (R. M. Black and Associates) between 1982 and 1984. Over that time, UWA's involvement in the WA Branch of the Society diminished significantly. ${ }^{31}$ However, the main change in the composition of the Society's WA Branch Committee occurred with the shift in the 'academic' centre of gravity, with WAIT becoming a dominant influence on the committee, starting with Norm Dufty's presidency for the period 1976-1978 but most significantly from the mid-1980s during Margaret Nowak's presidency in the period 1985-1987, and then Curtin and Murdoch University becoming more influential with Peter Kenyon's presidency in 1988-1991. The office bearers for the WA Branch of the Economic Society are reported more fully in Appendix 4.

By the late 1970s professors and heads of department from UWA's economics program did not seek administrative posts on the WA Branch of the Economic Society ${ }^{32}$ and members of the newer universities filled that vacuum. Consequently, when the WA Branch acted decisively to engage with members of the Society from other states by organising the Australian Conference of Economists, the conferences were convened in August 1984 at WAIT, with WAIT's Margaret Nowak organising the event, and in September 1993 with Murdoch University. It should also be acknowledged that, from the mid-1980s to the early 1990s, the WA College of Advanced education / Edith Cowan University played a role, with Tom Draber working as Treasurer for an extended period.

It is therefore not surprising that when the WA Branch presented its inaugural Austin Holmes Award, ${ }^{33}$ an award made in recognition of outstanding contributions to economics in this State, it was not made to a UWA economist. Rather, it was presented to Norman Dufty, from Curtin University, in 1968. The award was presented again in the following year to Donald Frearson, the inaugural Head of Economics at WAIT. However, The Austin Holmes Award was presented to Reginald

\footnotetext{
${ }^{31}$ Although, it should be noted that Douglas Vickers was a committee member of the WA Branch for much of his time, even serving as a Vice President in 1977. Wayne Frank was also Treasurer in the five years to 1973 .

${ }_{32}$ Michael McAleer made a brief appearance on the WA committee in late 1991.

${ }^{33}$ Prior to the introduction of the 'Austin Holmes's award, the 'Economic Society' award was given at a time when the Society's WA Branch was mainly presided over by representatives from industry and public service, with awards made to Sir Charles Court and Sir Harry Sorensen. In 1984, the Award was also presented to Alexander Kerr.
} 
Appleyard in 1992: the last UWA professor to preside over the WA Branch of the Economic Society.

\section{Conclusion: The Wild West or the Progressive West?}

In 1963 two proposals were approved for the UWA economics program: the introduction of a unit in monetary economics and a plan for enhancing the role of economic history. Given the conditions that prevailed, these were sound decisions. Monetary economics is an essential component of a quality economics program and the unit has endured to this day. Economic history is also a very desirable feature of an economics program. Once the plan was implemented - with a professor of economic history appointed and an economic history unit offered in each of the three undergraduate years plus the honours year, the deficiency in the program had been corrected.

However, from the 1970s and into the 1980s, the economic program overcorrected by introducing too many units from within the economic history stream. While many economic history teachers were active in research and in teaching core economics units ${ }^{34}$, or were training as researchers in economic history and were to become active later, this was not the case for all staff. Moreover, a complacency in regard to the importance of research in academic life extended across areas of core economic enquiry, with some problems evident by the time of Douglas Vickers's arrival at UWA in the early 1970s. However, in the mid-1970s, successful steps were taken to enhance research, such as through the appointment of a Roger Bowden as professor of applied economics. By the early 1980s, the appointment of Kenneth Clements as professor of economics further enhanced the research orientation of the economics department. Notwithstanding this progress, the department was still somewhat fragmented in the mid-1980s, with each professor working more or less independently of the other.

The real turnaround in the department's fortunes came between the late 1980s and the early 1990s and can be attributed to a number of factors, including: the establishment of the Economic Research Centre, which contributed to research training while attracting strong research oriented economists to UWA who publish in high quality peer reviewed journals; the Review of the Economics Department, which led to the introduction of a more balanced teaching program; and the institution of the $\mathrm{PhD}$ Conference, which exposed WA post graduate researchers to the research of post graduates from outside the State.

The thirty years of economics at UWA represents a successful progression that culminated in an improvement in the direction and quality of the economics program. Over the same period, the activities of the WA Branch of the Economic Society were also a success, especially the Shann memorial lecture that the Society convened (and still convenes) jointly with UWA. With the emergence of new colleges of advanced education and later new universities, however, participation by senior UWA staff in the activities of the WA Branch of the Society diminished progressively and rapidly.

${ }^{34}$ Pamela Statham taught first year microeconomics for many rears 
From the mid-1970s the presidential leadership role within the Branch had shifted, primarily to WAIT / Curtin University and Murdoch University.

* Economics Program (M251), University of Western Australia, Business School, 35 Stirling Highway, WA 6009 AUSTRALIA. Prepared for the 22nd Conference of the History of Economic Thought Society of Australia (HETSA) at the University of Notre Dame Australia, 14-17 July 2009 Email: Michael.mclure@uwa.edu.au

\section{References}

Appleyard, Reginald 1964. British Emigration to Australia, Canberra: Australian National University

Appleyard, Reginald 1970. Immigration: Policy and Progress, Australian Institute of Political Science. Monograph No. 7, Sydney: Southwood Press.

Appleyard, Reginald 1976. Socio-economic determinants of assisted emigration from the United Kingdom to Australia, Michigan: Ann Arbor.

Appleyard, Reginald 1988. Ten Pound Immigrants, London: Boxtree

Appleyard, Reginald and Manford, Toby 1979. The Beginning: European Discovery and Early Settlement of Swan River, Western Australia, Nedlands: UWA Press.

Appleyard, Reginald 1988. International Migration Today: Trends and Prospects Paris: UNESCO

Appleyard, Reginald forthcoming Power and Influence of the Business and Law Faculties on the Administration and Governance of the State, and in the Private Sector, Draft Chapter for the 2011 University of Western Australia Centennial Publication.

Appleyard, Reginald and Ghosh, R. N. 1988. Indian Ocean Islands Development, Canberra: National Centre for Development Studies, ANU and Centre for Migration \& Development Studies, University of Western Australia

Aron, Yitzhak (ed.) 1960 Middle East Record I, Jerusalem: Jerusalem Post Press for the Israel Oriental Society

Aron, Yitzhak (ed.) 1961 Middle East Record II, Jerusalem: Jerusalem Post Press for the Israel Oriental Society

Bowen, Ian. 1947. Britain's Industrial Survival, London: Faber.

Bowen, Ian. 1954. Population, London: J.Nisbet.

Bowen, Ian. 1976. Economics and Demography. London: George Allen and Unwin.

Bowden, Roger 1978. The Econometrics of Disequilibrium, Amsterdam: NorthHolland.

Bowden, Roger and Turkington, Darrell 1984. Instrumental Variables, Cambridge: Cambridge University Press.

Butlin, N. Ginswick, J Statham, P. 1986 Colonial statistics before 1850, Canberra : Australian National University 
Cannegieter, C. A. 1964. "Some Socio-economic Aspects of the Ord River Scheme", Economic Record. Vol. 40, pp: 375-391

Clements, Kenneth W. 1980 'A General Equilibrium Econometric Model of the Open Economy', International Economic Review, 21, pp. 469-88.

Clements, K. W. and Sjaarstad, L. 1984. How Protection Taxes Exporters, Thames Essay No. 39, London: Trade Policy Research Centre.

Clements, K. W. and Theil, H. 1987 Applied Demand Analysis: Results from SystemWide Approaches, Cambridge Mass.: Ballinger Publishing.

Clarkson, Leslie A.1976. Death, Disease, and Famine in Pre-industrial England, London and Ley York: St. Martin's Press

Clarkson, Leslie A. 1985 Proto-industrialisation: the First stage of Industrialisation, Basingstoke: Macmillan

Clarkson, Leslie A. 2004. A University in Troubled Times: Queen's Belfast, 19452000, Belfast: Four Courts

Crompton, Paul 2004. Australian Macroeconomic Policy Debates: Contributions from the Shann Memorial Lectures 1991-2000, Nedlands: UWA Press.

Davies, Mel 1982. 'Corsets and Conception: Fashion and Demographic Trends in the Nineteenth Century ', Comparative Studies in Society and History, 24(4), pp. 611-641

Davies, Mel 1989 'Establishing South Australia' in Statham, P.(ed) Origins of Australia's Capital Cities, Cambridge: Cambridge University Press

Dowsett, W. T 1959. Elementary Mathematics in Economics, Nedlands: UWA Press

Dowsett, W. T 1968. Poverty in Australia, Perth: Fabian Society of Western Australia

Eltis, Walter 1975 'Adam Smith's Theory of Economic Growth', in Andrew Skinner and Thomas Wilson (eds) Essays on Adam Smith, Oxford: Clarendon Press

Flatau, Paul and Leeson, Robert 2001. 'Ray Petridis, HETSA and the Revival of the History of Economics', History of Economics Review, 34, pp.1-6.

Gabbay, Rony 1954. 'The Economic History of the Jews in Baghdad and Basra in the $18^{\text {th }}$ and the $19^{\text {th }}$ Centuries', Law and Economics, 23(6), 1954, pp. 12-44.

Gabbay, Rony 1978. Communism and Agrarian Reform in Iraq, London: Croom Helm.

Gabbay, Rony Ghosh, R. N 1992. Economic Development in a Small Island Economy: A study of the Seychelles Marketing Board, Perth: Academic Press International.

Gabbay, Rony Ghosh, R. N. and Siddique, M.A.B. 1996 Economics of Small Island Nations, New Delhi: New Age International

Geographical Association of Western Australia 2009, GAWA Bulletin, February, p. 2123. Available online at: http://www.gawa.asn.au/Website\%202009/News\%20and\%20events/Gentilli\%2 0Award\%20Application\%20for\%20website.pdf

Ghosh, R. N. 1963. 'Malthus on Emigration and Colonization: Letters to WilmontHorton', Economica, New Series, 30(117), pp. 45-62 
Ghosh, R. N. 1964. 'The Colonization Controversy: Wilmont-Horton and the Classical Economists', Economica, New Series, 31(124), pp. 385-400

Ghosh, R. N. 1967. Classical Macroeconomics and the Case for Colonies, Calcutta: New Age Press

Ghosh, R. N. 1977. Agriculture in Economic Development, New Delhi: Vikas Publishing

Ghosh, R. N. 1984 'Adam Smith on Capital Accumulation and Growth', UWA Working Paper

Ghosh, R. N. 1985 'John Stuart Mill on colonies and colonization', UWA Working Paper, reprinted in John Cunningham Wood (ed) John Stuart Mill: Critical Assessments, 1987. Croom Helm, London

Goodwyn, C. 1968 'Classical Macroeconomics and the Case for Colonies by R. N. Ghosh' Economica, 35(139), pp. 313-14

Gregory, R. G., Takayama, Takashi, Clements, Kenneth W. 1991. International Economics Postgraduate Research Conference Volume, supplement to the Economic Record.

Karasinski, John (1981) Directory of Members, Perth: Economic Society of Australia and New Zealand, W.A. Branch

Leeson, Robert 2001. History of Economics Review: Special Issue in Honour of Ray Petridis, HER No34: HETSA

Lodewijks, John 2007. 'A Conversation with Helen Hughes', Journal of the Asia Pacific Economy, 12(4), pp. 429-451

Moir, Reg 1988. 'Agriculture' in de Garis, Brian (ed) 1988. Campus in the Community: the University of Western Australia, 1963-1987, Nedlands, W.A.: University of Western Australia Press, 1988, pp 195-208?

Musgrave, W. F. and Lews J. N. 1965. Measuring the Value of Political Argumnets A Comment on Cannegieter, Economics Record, 41(94), pp. 262-266

Qiang Ye. and Clements Kenneth W. 1999. 'Ten Years of the PhD Conference in Economics and Business'; Economic Record, 75, pp301-12.

Siddique Muhammed Abu B. 2001. International migration into the 21st century: essays in honour of Reginald Appleyard Cheltenham: Edward Elgar

Siddique Muhammed Abu B. 1993. A Decade of Shann Memorial Lectures 1981-90 and the Australian Economy, Singapore Academic Press International

Snooks, Graeme 1974. Depression and Recovery in Western Australia, 1928/29 1938/39: a Study in Economic Change, Nedlands: UWA Press.

Statham, Pamela 1981. Swan River Colony 1829-1850, in C. T. Stanage (ed), A New History of Western Australia, Nedlands: UWA Press., pp.181-210

Statham, Pamela 1988. The Australian Sandalwood Trade - Small but Significant, Canberra: Australian National University

Statham, Pamela 1989 Origins of Australia's Capital Cities, Cambridge: Cambridge University Press 
Statham-Drew, Pamela 2003. James Stirling: Admiral and Founding Governor of Western Australia, Nedlands: UWA Press.

Takayama, Takashi and Judge, George G. 1971 Spatial and Temporal Price and Allocation Models. North Holland

Takayama, Takashi . 1994. "Thirty years with spatial and intertemporal economics", Annals of Regional Science, 28(3), pp 305-322.

Tolomei, Aimee 2005. Dr Arnold Charles Cook, Association for the Blind of WA: http://www.abwa.asn.au/drarnoldcharlescook.htm

Treloar, David 1988. 'Economics and Commerce' in de Garis, Brian (ed) 1988. Campus in the Community: the University of Western Australia, 1963-1987, Nedlands: University of Western Australia Press, pp. 263-280

vanden Driesen, I. H 1986, Essays on Immigration Policy and Population in Western Australia 1850-1901 Nedlands: UWA Press.

vanden Driesen, I. H 1994. A Concise History of the Trade union Movement from Early Times to 1946, London: Avon

Vickers, Douglas 1975. "Finance and False Trading in Non-Tatonnement Markets" Australian Economic Papers, 14 (25) pp. 171- 186.

Vickers, Douglas 1978. Financial Markets in the Capitalist Process University of Pennsylvania Press.

Winch, Donald 1965. Classical Political Economy and Colonies, London: Bell.

Wood, John C. 1987 John Stuart Mill: Critical Assessments, London: Croom Helm 
Appendix 1: UWA Economics - PhD Dissertations: 1963 to 1993

1973

Lourens, R. The Perth Building Society: A Study in Institutional Growth

1977

Adam, C. Decision Process in Monetary Policy

Hoang, D.N. World Food Projection Models and Short-run World Trade and Reserve Policy Evaluations

1978

Savery, L. Dissatisfied Labour Turnover and Managerial Styles

1980

Ameer Ali. Some Aspects of Religio-economic Precepts and Practices in Islam: A Case Study of the Muslim Community in Ceylon during the Period 1800-1915

Statham, P. The Economic Development of the Swan River Colony, 1829-1850

1982

Kehal, H.S. Structural Changes in the Punjab Economy with Special Reference to Agriculture

1983

Fernando, G.W. An Empirical Approach to Pricing Policy

1985

Yeboah, D. A Control Theory Approach to Analysis of Economic Policy for Ghana

1987

Siddique, A. Some Aspects of the Growth of the Tea Industry in Assam (18341940): A Critical Evaluation of Government Policy

1988

Inyang, B.J. Trade Unions in Nigeria: A study of the major trends in their development from early times to 1979

Sawers, K.M. Import Competition in Australian Manufacturing Industries

Selvanathan, S. A System-wide Analysis of International and Interregional Consumption Patterns

1990

Manzur, M. Essays in Exchange Rate Economics

1991

Kiripat, S. An Economic Analysis of the Growth of the Rubber Industry in Thailand (1970 - 1988)

1993 
Chen, D. World Consumption Economics

Appendix 2: UWA Economics - Selection of Masters Dissertations: 1963 to 1993

1963

Faichampa, S Some Aspects of Financing Economic Development in Underdeveloped Countries

1965

Glynn, S The State and Primary Production: a Study of the Economic

Development of the Western Australian Wheat Belt, 1900-1930

1966

Harman, F. The Development of the Official Short-term Money Market in Australia

1967

Dolin, J. E. The Timber Industry of Western Australia: a Study of Organisation and Competition

1968

Snooks, G. D. Depression and Recovery in Western Australia, 1928/29 - 1938/39: a Study in Economic Change

1969

Bonds, A. T. The Economics of Outer Harbour Development in the Port of Fremantle: 1955 to 1965

1971

Lalich, W. F. The Latin American Free-trade Association: an Analysis of its Formation

1972

Ho, K. N. A Problems of Optimisation in Electricity Generation

1973

McBeath, D.D. The Shop Steward and Industrial Relations: a Study of the Western Australian Metal Trades

1976

Court, H. M Industrial Relations Disputes in the Pilbara Iron Ore Mining Industry: a Study of Labour-management Relations in a Developing Region.

1978

Hastings, L. R Some Aspects of the Economics of Welding In Structural Engineering 
Barnett, C. J. A Hedonic Price Model of Consumer Demand for Urban Residential Land

1983

Manzur, M. An Economic Analysis of the Rural Financial Markets In Bangladesh 1985

Giles, M An Economic Appraisal of Optimal Public Transport Subsidies

1987

Selvanathan, E Advertising and Consumption: a Theoretical Analysis

1988

Choi, K-H. Essays in Economic Aspects of Protection

1989

Roberts, E. J. The Demand for Meat: a System-wide Approach

1991

Salerian, S. N. The Theory of Competition and the Deregulation of the General Freight Market in Western Australia

1993

Dharmapala, D. The Methodology of Econometrics: Perspectives from the Philosophy of Science 


\section{Appendix 3: Shann Memorial Lectures: 1963 to 1993}

\begin{tabular}{|c|c|}
\hline 1963 & H.C. Coombs \\
\hline 1964 & Frank Traver de. Vyver \\
\hline 1965 & R.S. Sayers \\
\hline 1966 & Frank A. Waring \\
\hline 1967 & John Hicks \\
\hline 1968 & John Crawford \\
\hline 1969 & Herbert Burton \\
\hline 1970 & Lloyd Reynolds \\
\hline 1971 & Ian Bowen \\
\hline 1972 & Benjamin Higgins \\
\hline 1973 & Herbert G. Heneman \\
\hline 1974 & Keith Hancock \\
\hline 1975 & G. C. Harcourt \\
\hline 1976 & W.A. Sinclair \\
\hline 1977 & Malcolm R. Fisher \\
\hline 1978 & \\
\hline 1979 & \\
\hline 1980 & Robert S. Ozaki \\
\hline 1981 & Alan Powell \\
\hline 1982 & J.E. Issac \\
\hline 1983 & P.D.Groenewegen \\
\hline 1984 & John O. Stone \\
\hline 1985 & F.H. Gruen \\
\hline 1986 & H.W. Arndt \\
\hline 1987 & R.A. Johnston \\
\hline 1988 & John Dawkins \\
\hline 1989 & Noel Butlin \\
\hline 1990 & Ross Garnaut \\
\hline 1991 & Peter A. Walsh \\
\hline 1992 & Kenneth F. Wallis \\
\hline 1993 & Graeme Snooks \\
\hline
\end{tabular}

Some ingredients for growth

Arbitration: its differences and its drawbacks

Ideas in American central banking

Foreign economic policy: the American view

Monetary theory and policy

The development of trade policy

The Australian economy 1929-1969

Western economics in non-Western economies

Inflation and social justice

What do economists know now?

The university as usual in an unusual world

Economists ecologists and historians

Theoretical controversy and social significance

Australian economic development: old model and new model

The employment prospect

No lecture given

No lecture given

Groupism and Japanese Economic Growth

Resources and resource allocation policy

Economics and industrial relations

Rationalising Australian taxation revisited

1929 and all that...'

How badly is the Australian economy performing and why?

Australia and Indonesia: neighbours forever

Monetary policy: some lessons from history

Industrial Training: the forgotten fundamental for economic change

The great Australian take-over bid

The market and the State in economic development: lessons from East Asia and Australia

Errors and achievements: economic policy in the 1980's

On macroeconomic policy and macroeconometric models

Does the long-run in economics matter? A timely approach to the present and future 
Appendix 3: Office Holders, WA Branch of the Economic Society of Australia: 1963 to $1992-93^{35}$

\begin{tabular}{|c|c|c|c|c|}
\hline Year & President & Vice President & $\begin{array}{l}\text { Secretary / } \\
\text { Treasurer }\end{array}$ & $\begin{array}{l}\text { Committee } \\
\text { Member }\end{array}$ \\
\hline 1963 & Ian Bowen & $\begin{array}{l}\text { JD Colquhoun- } \\
\text { Denvers } \\
\text { B.W.A Lindsey }\end{array}$ & $\begin{array}{l}\text { LH Pyke } \\
\text { RV Garland }\end{array}$ & $\begin{array}{l}\text { J Hutton } \\
\text { AM Kerr } \\
\text { NF Laing } \\
\text { LE McCarrey } \\
\text { CA Vargovic }\end{array}$ \\
\hline 1964 & Ian Bowen & $\begin{array}{l}\text { JD Colquhoun- } \\
\text { Denvers } \\
\text { BWA Lindsey }\end{array}$ & $\begin{array}{l}\text { RL Smyth } \\
\text { RV Garland }\end{array}$ & $\begin{array}{l}\text { JE Dolin } \\
\text { WG Dufty } \\
\text { NF Dufty } \\
\text { NF Laing } \\
\text { LE McCarrey } \\
\text { CA Vargovic }\end{array}$ \\
\hline 1965 & $\begin{array}{l}\text { Alexander } \\
\text { Kerr }\end{array}$ & $\begin{array}{l}\text { JD Colquhoun- } \\
\text { Denvers } \\
\text { HA Jone }\end{array}$ & $\begin{array}{l}\text { JE Dolan } \\
\text { RV Garland }\end{array}$ & $\begin{array}{l}\text { AM Blain } \\
\text { DH Briggs } \\
\text { T Burgess } \\
\text { NF Dufty } \\
\text { LE McCarrey } \\
\text { CA Vargovic }\end{array}$ \\
\hline 1966 & $\begin{array}{l}\text { Alexander } \\
\text { Kerr }\end{array}$ & $\begin{array}{l}\text { HA Jones } \\
\text { CA Vargovic }\end{array}$ & $\begin{array}{l}\text { W Frank } \\
\text { D Briggs }\end{array}$ & $\begin{array}{l}\text { AT Blonds } \\
\text { B Boylson } \\
\text { WT Browne } \\
\text { T Burgess } \\
\text { NF Duffy } \\
\text { JE Dolin }\end{array}$ \\
\hline $\begin{array}{l}1967 \\
1968\end{array}$ & $\begin{array}{l}\text { na } \\
\text { na }\end{array}$ & $\begin{array}{l}\text { na } \\
\text { na }\end{array}$ & $\begin{array}{l}\text { na } \\
\text { na }\end{array}$ & $\begin{array}{l}\text { na } \\
\text { na }\end{array}$ \\
\hline 1969 & $\begin{array}{l}\text { Alexander } \\
\text { Kerr }\end{array}$ & $\begin{array}{l}\text { R J McKenna } \\
\text { F Malone }\end{array}$ & WR Frank & $\begin{array}{l}\text { R Appleyard } \\
\text { A Barrett } \\
\text { FS Cross } \\
\text { NF Duffy } \\
\text { TA Lawson } \\
\text { DD McBeath } \\
\text { N Smith } \\
\text { DWG Treloar }\end{array}$ \\
\hline 1970 & RJ McKenna & $\begin{array}{l}\text { R Appleyard } \\
\text { TA Lawson }\end{array}$ & WR Frank & $\begin{array}{l}\text { A Barrett } \\
\text { FS Cross } \\
\text { NF Duffy } \\
\text { HA Jones } \\
\text { DD McBeath } \\
\text { N Smithson } \\
\text { DWG Treloar }\end{array}$ \\
\hline
\end{tabular}

${ }^{35}$ UWA academic staff shown in bold. 


\begin{tabular}{|c|c|c|c|c|}
\hline Year & President & Vice President & $\begin{array}{l}\text { Secretary / } \\
\text { Treasurer }\end{array}$ & $\begin{array}{l}\text { Committee } \\
\text { Member }\end{array}$ \\
\hline 1971 & RJ McKenna & $\begin{array}{l}\text { R Appleyard } \\
\text { TA Lawson }\end{array}$ & WR Frank & $\begin{array}{l}\text { A Barrett } \\
\text { FS Cross } \\
\text { NF Duffy } \\
\text { HA Jones } \\
\text { DD McBeath } \\
\text { N Smithson } \\
\text { DWG Treloar }\end{array}$ \\
\hline 1972 & TA Lawson & $\begin{array}{l}\text { R Appleyard } \\
\text { NF Dufty }\end{array}$ & $\begin{array}{l}\text { JJ Ryan } \\
\text { WT Frank }\end{array}$ & $\begin{array}{l}\text { A Barrett } \\
\text { FS Cross } \\
\text { JR Ewing } \\
\text { R Harrold } \\
\text { HA Jones } \\
\text { AM Kerr } \\
\text { DD McBeath }\end{array}$ \\
\hline 1973 & $\begin{array}{l}\text { Reginald } \\
\text { Appleyard }\end{array}$ & $\begin{array}{l}\text { NF Dufty } \\
\text { JR Ewing }\end{array}$ & $\begin{array}{l}\text { R Harrold } \\
\text { WT Frank }\end{array}$ & $\begin{array}{l}\text { FS Cross } \\
\text { T Draber } \\
\text { T Hogan } \\
\text { HA Jones } \\
\text { DD McBeath } \\
\text { JJ Ryan } \\
\text { D Vickers }\end{array}$ \\
\hline 1974 & JR Ewing & $\begin{array}{l}\text { NF Dufty } \\
\text { T. Hogan }\end{array}$ & R Harrold & $\begin{array}{l}\text { FS Cross } \\
\text { RA Greig } \\
\text { HA Jones } \\
\text { T McHenry } \\
\text { D Vickers } \\
\text { P Whyte }\end{array}$ \\
\hline 1975 & JR Ewing & $\begin{array}{l}\text { NF Dufty } \\
\text { T. Hogan }\end{array}$ & $\begin{array}{l}\text { J Krasnostein } \\
\text { T Draber }\end{array}$ & $\begin{array}{l}\text { B Brown } \\
\text { NF Dufty } \\
\text { RA Greig } \\
\text { R Harrold } \\
\text { T Hogan } \\
\text { T McHenry } \\
\text { P Whyte }\end{array}$ \\
\hline 1976 & Norm Dufty & $\begin{array}{l}\text { NF Dufty } \\
\text { T Hogan }\end{array}$ & $\begin{array}{l}\text { J Krasnostein } \\
\text { T Draber }\end{array}$ & $\begin{array}{l}\text { R Appleyard } \\
\text { J Dolin } \\
\text { T Hogan } \\
\text { G Hancock } \\
\text { AMD James } \\
\text { AM Kerr } \\
\text { D Vickers }\end{array}$ \\
\hline
\end{tabular}




\begin{tabular}{|c|c|c|c|c|}
\hline Year & President & Vice President & $\begin{array}{l}\text { Secretary / } \\
\text { Treasurer }\end{array}$ & $\begin{array}{l}\text { Committee } \\
\text { member }\end{array}$ \\
\hline 1977 & Norm Dufty & $\begin{array}{l}\text { T Hogan } \\
\text { D Vickers }\end{array}$ & A Barrett & $\begin{array}{l}\text { R Appleyard } \\
\text { ANJ Blain } \\
\text { J Dolin } \\
\text { G Hancock } \\
\text { AMD Jones } \\
\text { AM Kerr } \\
\text { J Lyall }\end{array}$ \\
\hline 1978 & Norm Dufty & $\begin{array}{l}\text { T Hogan } \\
\text { R Appleyard }\end{array}$ & A Barrett & $\begin{array}{l}\text { J Dolin } \\
\text { G Hancock } \\
\text { J Karasinski } \\
\text { J Lyall } \\
\text { B Paterson }\end{array}$ \\
\hline 1979 & Terrance Hogan & $\begin{array}{l}\text { JL Lyall } \\
\text { R Appleyard }\end{array}$ & A Barrett & $\begin{array}{l}\text { J Dolin } \\
\text { G Hancock } \\
\text { J Karasinski } \\
\text { AM Kerr } \\
\text { B Krost }\end{array}$ \\
\hline 1980 & Terrance Hogan & $\begin{array}{l}\text { JL Lyall } \\
\text { B Krost }\end{array}$ & G Hancock & $\begin{array}{l}\text { RT Appleyard } \\
\text { A Barrett } \\
\text { JR Ewing } \\
\text { J Karasinski } \\
\text { AM. Kerr } \\
\text { N Leigh }\end{array}$ \\
\hline 1981 & Jeannie M Lyall & G Hancock & M Syropoulo & $\begin{array}{l}\text { RT Appleyard } \\
\text { JR Ewing } \\
\text { G Forster } \\
\text { IA Kerr } \\
\text { B Krost } \\
\text { N Leigh } \\
\text { M Nowak }\end{array}$ \\
\hline 1982 & Greg Hancock & $\begin{array}{l}\text { M Nowak } \\
\text { G Forster }\end{array}$ & $\begin{array}{l}\text { K Roberts } \\
\text { M Syropoulo }\end{array}$ & $\begin{array}{l}\text { I Kerr } \\
\text { J Leaper } \\
\text { N Leigh } \\
\text { G Crockett } \\
\text { J Lyall } \\
\text { T Draber }\end{array}$ \\
\hline
\end{tabular}




\begin{tabular}{|c|c|c|c|c|}
\hline Year & President & Vice President & $\begin{array}{l}\text { Secretary / } \\
\text { Treasurer }\end{array}$ & $\begin{array}{l}\text { Committee } \\
\text { member }\end{array}$ \\
\hline 1983 & Greg Hancock & na & $\mathrm{Na}$ & $\begin{array}{l}\text { G Hancock } \\
\text { M Nowak } \\
\text { K Roberts } \\
\text { M Syropoulo } \\
\text { N Leigh } \\
\text { G Crockett } \\
\text { G Murray } \\
\text { J Lyall } \\
\text { J Karasinski }\end{array}$ \\
\hline 1984 & Greg Hancock & na & K Roberts & $\begin{array}{l}\text { G Hancock } \\
\text { M Syropoulo } \\
\text { M Nowak } \\
\text { J Lyall } \\
\text { T Draber } \\
\text { N Leigh } \\
\text { J Karasinski }\end{array}$ \\
\hline 1985 & $\begin{array}{l}\text { Margaret } \\
\text { Nowak }\end{array}$ & $\begin{array}{l}\text { Peter Kenyon } \\
\text { John Karasinski }\end{array}$ & $\begin{array}{l}\text { Wendy } \\
\text { Boddington } \\
\text { Mark } \\
\text { Syropoulo }\end{array}$ & $\begin{array}{l}\text { T Draber } \\
\text { J Lyall } \\
\text { K Noris } \\
\text { G Murray } \\
\text { J Jackson } \\
\text { F Harmon } \\
\text { B Martin } \\
\text { D Frearson } \\
\text { J Roberts } \\
\end{array}$ \\
\hline $\begin{array}{l}1986 / 8 \\
7\end{array}$ & $\begin{array}{l}\text { Margaret } \\
\text { Nowak }\end{array}$ & $\begin{array}{l}\text { Peter Kenyon } \\
\text { Michael Thorpe }\end{array}$ & $\begin{array}{l}\text { Wendy } \\
\text { Boddington } \\
\text { Tom Draber }\end{array}$ & $\begin{array}{l}\text { D Freaerson } \\
\text { C Reynoldson } \\
\text { R Leeson } \\
\text { P McLeod } \\
\text { A Langford } \\
\text { R Wood }\end{array}$ \\
\hline $\begin{array}{l}1887 / 8 \\
8\end{array}$ & $\begin{array}{l}\text { Margaret } \\
\text { Nowak }\end{array}$ & na & $\begin{array}{l}\text { na } \\
\text { Wendy } \\
\text { Boddington } \\
\text { (?) } \\
\text { Tom Draber } \\
(?)\end{array}$ & $\begin{array}{l}\text { M Nowak } \\
\text { W Boddington } \\
\text { T Draber } \\
\text { C Reynoldson } \\
\text { J Pope } \\
\text { R Leeson } \\
\text { P Lewis } \\
\text { Alan Langford } \\
\text { P Maxwell }\end{array}$ \\
\hline
\end{tabular}




\begin{tabular}{|c|c|c|c|c|}
\hline Year & President & Vice President & $\begin{array}{l}\text { Secretary / } \\
\text { Treasurer }\end{array}$ & $\begin{array}{l}\text { Committee } \\
\text { member }\end{array}$ \\
\hline 1988/89 & Peter Kenyon & na & $\begin{array}{l}\text { na } \\
\text { Tom Draber }\end{array}$ & $\begin{array}{l}\text { M Nowak } \\
\text { W Boddington } \\
\text { T Draber } \\
\text { C Reynoldson } \\
\text { J Pope } \\
\text { R Leeson } \\
\text { P Grossman } \\
\text { P Maxwell } \\
\text { M McLure }\end{array}$ \\
\hline 1989/90 & Peter Kenyon & $\begin{array}{l}\text { M Nowak } \\
\text { P Maxwell }\end{array}$ & $\begin{array}{l}\text { Robert } \\
\text { Leeson } \\
\text { Tom Draber }\end{array}$ & $\begin{array}{l}\text { M Nowak } \\
\text { C Reynoldson } \\
\text { C Short } \\
\text { P Lewis } \\
\text { M McLure } \\
\text { A Siddique } \\
\end{array}$ \\
\hline 1990/91 & Peter Kenyon & $\begin{array}{l}\text { M Nowak } \\
\text { P Maxwell }\end{array}$ & $\begin{array}{l}\text { Robert } \\
\text { Leeson } \\
\text { Tom Draber }\end{array}$ & $\begin{array}{l}\text { M Nowak } \\
\text { C Reynoldson } \\
\text { C Short } \\
\text { P Lewis } \\
\text { Y Melotte } \\
\text { A Siddique } \\
\end{array}$ \\
\hline 1991/92 & $\begin{array}{l}\text { Philip } \\
\text { Maxwell }\end{array}$ & M. Thorp & $\begin{array}{l}\text { Gary } \\
\text { MacDonald } \\
\text { Tom Draber }\end{array}$ & $\begin{array}{l}\text { M Brennan } \\
\text { P Lewis } \\
\text { Y Melotte } \\
\text { D Butler } \\
\text { M. Nowak } \\
\text { J. Wood } \\
\text { D Stott } \\
\text { N Cusworth } \\
\text { A Langford } \\
\text { M McAleer }\end{array}$ \\
\hline
\end{tabular}

Source: Karasinski (1981) for 1963-1981 and Society Records from 1982 to 1991-92 (but are sometimes incomplete i.e. with AGM minutes, needed to confirm appointments, often missing).

\section{Appendix 4: Fragmented Record of UWA Bateman Memorial Lectures:}

1990 Walter Eltis

1991 Douglas Vickers

1993 Paul Bernd Spahn
How inflation undermines industrial success

The long run and the short

The Bundesbank, Maastricht and world financial markets 